\title{
IMPLEMENTASI HAK ANAK YANG MELAKUKAN TINDAK PIDANA DI PENGADILAN NEGERI SIDOARJO
}

\author{
Siti Khoirul Nikmah \\ PSP3 Sandingtaman Panjalu Ciamis | sitikhoirulnikmah@gmail.com.
}

\begin{abstract}
This article is a field research on "implementation of child's rights who conducts crime according to Undang-Undang No. 3 Tahun 1997 in Pengadilan Negeri of Sidoarjo on the Islamic criminal law perspective". This study aims to answer the questions about the implementation of the child's rights who commits offense under Undang-Undang No. 3, tahun 1997 in Pengadilan Negeri of Sidoarjo and the view of the Islamic criminal law on the child's rights who commits crime. To answer the two main questions, the author uses descriptive analysis method. The research shows that the implementation of the child's rights who commits offense under Undang-Undang No. 3 tahun 1997 in Pengadilan Negeri of Sidoarjo during the process of examination in court are; entitling to an explanation of the procedure of the trial and the case, obtainning a legal counseling during the trial and a right to choose his own legal counsellor, communicating to his legal supervisor, getting an adequate facility in the trial, gaining protection against adverse actions, obtaining a right to express and defend his own opinion, getting a treatment as set out in the criminal code. In Islamic law, the judicial process of child who commits criminal acts is entitled to defense himself whether conducted by the child himself or his own legal counsellor and he also has right to ask a compensation for a wrong decision.
\end{abstract}

Keywords: Child's rights, crime, Undang-Undang, Islamic law.

Abstrak: Artikel ini membahas tentang implementasi hak Anak yang melakukan tindak pidana. limplementasi hak-hak anak yang melakukan tindak pidana menurut Undang-Undang No. 3 Tahun 1997 di Pengadilan Negeri Sidoarjo selama dalam proses pemeriksaan di persidangan adalah berhak mendapatkan penjelasan mengenai tata cara persidangan dan kasusnya, mendapatkan pendampingan penasehat hukum selama persidangan dan berhak memilih sendiri 
penasehat hukumnya, berhubungan langsung dengan penasehat hukum dengan diawasi tanpa didengar oleh pejabat berwenang, mendapatkan fasilitas ikut serta memperlancar persidangan mengenai dirinya, mendapatkan perlindungan terhadap tindakan-tindakan yang merugikan, yang menimbulkan penderitaan mental, fisik, sosial, mendapatkan hak untuk menyatakan pendapat dan membela dirinya, mendapatkan perlakuan pembinaan/penghukuman yang positif, yang masih mengembangkan dirinya sebagai manusia seutuhnya, dan memohon ganti kerugian atas perlakuan yang menimbulkan penderitaan, karena ditangkap, ditahan, dituntut, ataupun diadili tanpa alasan yang berdasarkan undang-undang atau karena kekeliruan mengenai orangnya atau hukum yang diterapkan menurut cara yang diatur dalam KUHAP. Dalam hukum Islam, dalam proses peradilan, anak yang melakukan tindak pidana berhak atas pembelaan dirinya baik yang dilakukan dirinya maupun bantuan dari penasehat hukum dan berhak meminta ganti rugi karena putusan yang salah.

Kata Kunci: Hak anak, tindak pidana, Undang-Undang, Hukum Islam.

\section{Pendahuluan}

Pembicaraan tentang anak dan perlindungannya tidak akan pernah berhenti sepanjang sejarah kehidupan, karena anak adalah generasi penerus bangsa dan penerus pembangunan yaitu generasi yang dipersiapkan sebagai subjek pelaksana pembangunan yang berkelanjutan dan pemegang kendali masa depan suatu negara. Perlindungan anak berarti melindungi potensi sumber daya insani dan membangun manusia seutuhnya menuju masyarakat yang adil dan makmur. ${ }^{1}$

Sebenarnya citra dan pengertian tentang manusia dan kemanusiaan merupakan faktor yang dominan dalam menghadapi dan menyelesaikan permasalahan perlindungan terhadap anak yang merupakan permasalahan kehidupan manusia. Di sini yang menjadi objek dan subjek pelayanan dan kegiatan perlindungan anak sama-sama mempunyai hak-hak dan kewajiban, motivasi seseorang untuk ikut serta secara tekun dan gigih dalam setiap

' Nashriana, Perlindungan Hukum Pidana Bagi Anak di Indonesia, (Jakarta: Raja Grafindo Persada, 20II), I. 
kegiatan perlindungan anak, pandangan bahwa setiap anak itu wajar dan berhak mendapat perlindungan mental, fisik, dan sosial dari orang tua, anggota masyarakat dan negara. Pandanganpandangan tersebut jelas berdasarkan pengertian dari citra yang tepat mengenai manusia tidak terkecuali manusia yang disebut dengan anak. Di sinilah masalah perlindungan anak adalah suatu masalah yang merupakan suatu kenyataan sosial. ${ }^{2}$

Pembangunan nasional yang merupakan proses modernisasi membawa dampak positif maupun negatif. Banyak peristiwa yang menarik perhatian masyarakat akhir-akhir ini yaitu dengan semakin banyaknya perbuatan-perbuatan pidana, delikuensi/kenakalan anak-anak. Kecenderungan meningkatnya kualitas maupun kuantitas pelanggaran baik terhadap ketertiban umum maupun pelanggaran terhadap ketentuan undang-undang oleh pelaku-pelaku muda usia, mengarah pada tindakan kriminal, mendorong kita untuk lebih banyak memberi perhatian akan penanggulangan serta penanganannya, khusus di bidang hukum pidana (anak) beserta hukum acaranya. Hal ini erat hubungannya dengan perlakuan khusus terhadap pelaku tindak pidana yang masih anak-anak. ${ }^{3}$

Satu contoh kasus di Batam Kepulauan Riau (Kepri) kembali dibuat mengelus dada. Sedikitnya sepuluh siswa SMP dan SMA ditangkap polisi karena terlibat aksi pencurian kendaraan bermotor (curanmor). Mereka menggasak dua motor sebelum tertangkap pada aksi ketiga. Mereka diringkus polisi setelah mencuri motor RX King di Bengkong Harapan, Batam, kemarin. ${ }^{4}$

Sangat memprihatinkan, kasus tindak kejahatan geng motor yang tengah terjadi di kota Pekanbaru Riau dengan didoktrinisasi oleh mantan residivis bernama Mardijianto alias Anto Klewang terhadap anak-anak remaja sekolah akhir-akhir ini. Pasalnya, tidak

${ }^{2}$ lbid., 2.

${ }^{3}$ Agung Wahyono dan Siti Rahayu, Tinjauan Tentang Peradilan Anak di Indonesia, (Jakarta: Sinar Grafika, 1993), 2.

${ }^{4}$ Soe, "Polisi Tangkap Kelompok Remaja Pencuri Motor", Jawa Pos, (9 April 20 I3), 17.

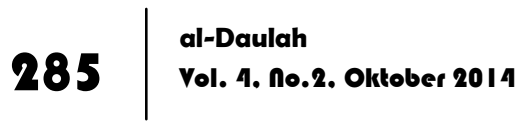


hanya kepolisian, orang tua, masyarakat, bahkan dunia pendidikan pun ikut menyayangkan aksi ulah geng motor yang meresahkan warga kota Pekanbaru ini. Kasus ini bisa dikategorikan dalam dua golongan. Golongan pertama dilakukan oleh pimpinan geng motor dan golongan kedua dilakukan oleh anak-anak usia remaja yang ikut dalam perkumpulan geng motor. Kasus Klewang masuk dalam ranah disidentitas diri. Dimana, anak-anak yang mulai kehilangan jati diri ketika bertemu dengan sosok Klewang yang notabene-nya punya kelebihan didepan anakanak akhirnya terpengaruh. Anak-anak yang krisis percaya diri. Setelah menemukan sosok Klewang dibentuk untuk berani. Bahkan tidak segan untuk berbuat perilaku yang menyimpang dari undang-undang yang berlaku, sehingga bisa digolongkan telah melakukan suatu tindak pidana. ${ }^{5}$

Masalah pembinaan generasi muda merupakan bagian integral dari masalah pembangunan. Oleh sebab itu sebagian masalah pembinaan yaitu pembinaan yustisial terhadap generasi muda khususnya anak-anak perlu mendapat perhatian secara khusus. Dalam proses perkembangan tidak jarang timbul perbuatan-perbuatan pidana yang dilakukan oleh anak-anak di bawah umur. Oleh sebab itu anak yang melakukan tindak pidana perlu diselesaikan melalui suatu lembaga peradilan khusus yaitu pengadilan anak agar ada jaminan bahwa penyelesaian tersebut dilakukan benar-benar untuk kesejahteraan anak yang bersangkutan dan kepentingan masyarakat, tanpa mengabaikan terlaksananya hukum dan keadilan. ${ }^{6}$

Masalah pokok peradilan anak adalah melibatkan anak dalam proses hukum sebagai subyek delik dengan tidak mengabaikan manfaat bagi hari depan anak tersebut, dan menegakkan wibawa hukum sebagai pengayom, pelindung, serta menciptakan iklim

5 Lihat Viva News, Belasan Anggota Geng Klewang Masih Anak-Anak, http://www.news.viva.co.id/read/25802/belasan-anggota-geng-motor-klewang-masih-anakanak, diakses 28 Mei 2013.

${ }^{6}$ Agung Wahyono dan Siti Rahayu, Tinjauan Tentang Peradilan Anak Di Indonesia, 2. 
yang tertib untuk memperoleh keadilan. Dengan demikian sejauh mana perlakuan yang harus diterapkan oleh aparat penegak hukum jika pada kenyataannya secara biologis, psikologis, dan sosiologis, kondisi fisik, mental dan sosial anak menempatkannya pada kedudukan khusus. ${ }^{7}$

Kemudian bagaimana Islam menyoroti problem semacam ini, adakah ketentuan hukuman yang bersifat efektif sehingga tidak menghilangkan hak-hak anak untuk diterapkan terhadap pelaku jarimah anak di bawah umur. Al-Qur'an dan hadits memberi muatan dengan pesan akhlak atau budi pekerti yang universal untuk keselamatan dan kebaikan anak. Sebagaimana QS. alLuqman (31): 17, sebagai berikut:

"Wahai anakku! Laksanakanlah shalat dan suruhlah (manusia) berbuat yang makruf dan cegahlah (mereka) dari yang mungkar dan bersabarlah terhadap apa yang menimpamu, sesungguhnya yang demikian itu termasuk perkara yang penting." ${ }^{8}$

Agar tidak terjadi dan untuk menghindari terjadinya kejahatan dan pelanggaran oleh anak di bawah umur, Islam sangat menekankan arti penting hubungan positif anak dengan orang tuanya sebelum yang bersangkutan berhubungan baik kepada diri sendiri dan orang lain. Permasalahan anak bukan permasalahan sepele, karena menyangkut tanggung jawab kepada Allah swt. Sebagai pemberi amanat, Allah swt menjadikan anak sebagai ujian bagi kedua orang tuanya sekaligus sebagai anugerah penerus keturunan dan hubungan kebaikan manakala orang tuanya sudah meninggal.

Agama Islam mengajarkan para pemeluknya untuk memberikan perlindungan terhadap anak. Perlindungan anak tersebut berupa kegiatan untuk jaminan dan melindungi anak dan hak-haknya sehingga dapat hidup, tumbuh, berkembang, dan berpartisipasi secara optimal sesuai dengan harkat dan martabat

${ }^{7}$ Ibid.

${ }^{8}$ Departemen Agama RI, A/-Quran dan Terjemahannya, (Bandung: Diponegoro, 2008), 4II. 
kemanusiaan, serta mendapat perlindungan dari setiap tindak kekerasan dan diskriminasi. ${ }^{9}$ Menelantarkan dan mensia-siakan anak sangat dilarang agama, sebagaimana firman Allah dalam QS. al-An'am (6): 140:

"Sesungguhnya rugilah orang-orang yang membunuh anakanak mereka karena kebodohan tanpa pengetahuan."10

Dalam hukum positif Indonesia, perlindungan hukum terhadap hak-hak anak dapat ditemui di berbagai peraturan perundang-undangan, seperti yang tertuang dalam Keputusan Presiden Nomor 36 Tahun 1990 pada tanggal 25 Agustus 1990, yang merupakan ratifikasi dari konvensi PBB, Konvensi tentang Hak-Hak Anak, Undang-Undang No. 4 Tahun 1979 tentang Kesejahteraan Anak, dan Undang-Undang No. 23 Tahun 2002 tentang Perlindungan Anak. Berdasarkan Undang-Undang No. 3 Tahun 1997 tentang Pengadilan Anak, terhadap anak-anak yang berhadapan dengan hukum yaitu anak sebagai pelaku tindak pidana, menurut Arief Gosita ada beberapa hak-hak anak yang harus diperjuangkan pelaksanaannya secara bersama-sama. ${ }^{11}$

Anak adalah bagian dari generasi muda, penerus cita-cita bangsa yang memerlukan pembinaan dan perlindungan dalam rangka menjamin pertumbuhan dan perkembangan fisik, mental dan sosial secara utuh, serasi, selaras, dan seimbang, yang belum memiliki kemampuan membedakan tindakan yang boleh dan tidak dibolehkan, sehingga acapkali akibat tindakannya mereka harus dihadapkan dengan hukum. Terhadap anak yang melakukan tindak pidana dimana mereka tidak bisa melindungi hak-haknya sendiri, perlu ada kontrol dari orang dewasa, dalam hal ini orang tua dan terkait proses beracara di peradilan tentunya bantuan hukum seorang penasehat hukum.

Dengan demikian, anak-anak yang nakal telah bersalah dan telah melakukan tindak pidana harus tetap diayomi, dilindungi,

\footnotetext{
${ }^{9}$ Ibnu Anshori, Perlindungan Anak Menurut Perspektif Islam, ( Jakarta: KPAI, 2007), I.

${ }^{10}$ Departemen Agama RI, Al-Quran dan Terjemahannya, 146.

" Nashriana, Perlindungan Hukum Pidana Bagi Anak di Indonesia, 20.
} 
diberi pelayanan dan asuhan serta pendidikan dan bimbingan sehingga dapat menjadi warga negara yang berguna bagi dirinya sendiri, masyarakat, nusa dan bangsa. Pengadilan anak yang diatur dalam Undang-undang No. 3 Tahun 1997 sebagai salah satu untuk mengupayakan terlaksanakanya hak-hak anak yang telah melakukan tindak pidana. Di mana pengadilan anak yang dilaksanakan di Pengadilan Negeri Sidoarjo merupakan salah satu pelaksana kekuasan kehakiman yang berada di lingkungan Peradilan Umum.

Berdasarkan penjelasan di atas, maka dalam makalah ini dirumuskan permasalahan sebagai berikut:

1. Bagaimana implementasi hak-hak anak yang melakukan tindak pidana menurut Undang-Undang No. 3 Tahun 1997 di Pengadilan Negeri Sidoarjo?

2. Bagaimana pandangan hukum acara pidana Islam terhadap hak-hak anak yang melakukan tindak pidana?

\section{Hak-Hak Anak yang Melakukan Tindak Pidana}

Anak tetaplah anak, dengan segala ketidakmandirian yang ada, mereka sangatlah membutuhkan perlindungan dan kasih sayang dari orang dewasa di sekitarnya. Anak mempunyai hak yang harus diimplementasikan dalam kehidupan dan penghidupan mereka, tidak terkecuali terhadap anak yang melakukan tindak pidana. Hak-hak anak yang melakukan tindak pidana dalam Undang-Undang No. 3 Tahun 1997 tentang Pengadilan Anak diatur dalam Pasal 45 ayat (4), dan Pasal 51 ayat (1) dan (3). Selain itu hak-haknya juga diatur dalam Bab IV Pasal 50 sampai dengan Pasal 68 KUHAP, kecuali Pasal 64-nya. ${ }^{12}$ Ini menunjukkan bahwa hak-hak anak yang melakukan tindak pidana selain mengacu pada hukum yang umum (KUHAP), tetapi juga diatur dalam hukum pidana anak (Undang-Undang No. 3 Tahun 1997 tentang Pengadilan Anak), karena Undang-Undang

12 Pasal 64 KUHAP berbunyi: terdakwa berhak untuk diadili di sidang pengadilan yang terbuka untuk umum. 
Pengadilan Anak tidak mencabut hak-hak anak yang melakukan tindak pidana dalam KUHAP, tetapi melengkapi apa yang diatur dalam KUHAP.

Dalam hukum Islam, seorang anak tak akan dikenakan hukuman had karena kejahatan yang dilakukannya. Karena tak ada tanggung jawab hukum atas seorang anak yang berusia berapapun sampai dia mencapai umur puber. Hakim hanya berhak menegur kesalahannya atau menetapkan beberapa pembatasan baginya yang akan memperbaikinya dan menghentikannya dari membuat kesalahan lagi di masa yang akan datang. ${ }^{13}$

Menurut syariat Islam pertanggungjawaban pidana didasarkan atas dua perkara, yaitu kekuatan berfikir dan pilihan. Oleh karena itu kedudukan anak kecil berbeda-beda menurut perbedaan masa yang dilalui hidupnya, mulai dari waktu kelahirannya sampai masa memiliki kedua perkara tersebut. Hasil penyelidikan para fuqaha menyatakan bahwa masa tersebut ada tiga, yaitu masa tidak adanya kemampuan berfikir, masa kemampuan berfikir lemah, dan masa kemampuan berfikir penuh.

Konsep yang dikemukakan oleh syariat Islam tentang pertanggungjawaban pidana anak belum dewasa menyamai teori terbaru di kalangan hukum positif. Hukum Romawi sebagai bentuk hukum positif yang paling maju pada masa turunnya syariat Islam dan yang menjadi dasar hukum-hukum Eropa modern, mengadakan pemisahan antara pertanggungjawaban anak-anak yang melakukan tindak pidana dengan pertanggungjawawaban tindak pidana yang dilakukan oleh orang dewasa dalam batas yang sempit sekali, yaitu usia tujuh tahun. Jadi apabila anak-anak telah berumur tujuh tahun ke atas, maka ia dikenakan pertanggungjawaban pidana sedang kalau belum mencapai usia tersebut, maka tidak dikenakan kecuali kalau ketika memperbuat jarimah ia mempunyai niatan untuk merugikan orang

${ }^{13}$ Abdur Rahman, Tindak Pidana dalam Syariat Islam, (Jakarta: Rineka Cipta, 1992), 16.

$290 \mid$\begin{tabular}{l|l} 
al-Daulah \\
Vol. 4. no.2. Oktober 2014
\end{tabular} 
lain, maka dalam hal ini dikenakan pertanggungjawaban pidana. ${ }^{14}$ Pada tahap pemeriksaan di sidang pengadilan, hukum acara pidana Islam memberi jaminan bagi terdakwa sebagai berikut.

1. Hak untuk membela diri

Hak ini merupakan hak yang sangat penting, karena dengannya terdakwa dapat menyangkal tuduhan terhadapnya baik melalui bantahan terhadap bukti yang memberatkan atau mengajukan bukti untuk pembebasan. Perlunya hak untuk membela diri menjadi jelas tatkala kita sadari bahwa suatu tuduhan yang tidak dibantah oleh tertuduh menjadi suatu bukti bahwa ia bersalah. Hak-hak yang berkaitan dan merupakan aspek-aspek praktis dari hak membela diri adalah sebagai berikut:

a. Terdakwa harus diberi informasi tentang tuduhan terhadapnya dan bukti-bukti yang ada dalam kasus itu, baik yang membuktikan atau yang membebaskan. Dia juga harus diberi tahu hal-hal yang berpengaruh di seputar kasus itu seluruhnya.

b. Terdakwa harus mampu membela dirinya sendiri. Hanafi berpendapat bahwa pelaku kejahatan yang bisu tidak boleh dijatuhi hukuman hudud walau bukti-bukti menunjukkan kesalahannya. Dia menopang pandangannya dengan mengatakan bahwa pelaku seperti itu kurang memiliki sarana untuk mengekspresikan pembelaannya, karena bahasa isyarat tidak cukup untuk memberi pembelaan penuh.

c. Terdakwa memiliki hak menyewa seorang pengacara untuk membantunya dalam pembelaan. Hal ini dapat menjadi persyaratan praktis dan hak untuk membela diri karena menghadapkan terdakwa dengan dakwaan yang mempengaruhi kejernihan akal pikirannya. Hal ini juga dapat menghilangkan kemampuan membela dirinya

${ }^{14}$ Ahmad Hanafi, Asas-Asas Hukum Pidana Islam, (Jakarta: Bulan Bintang, 1990), 368.

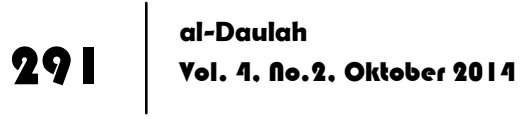


sendiri. Lebih jauh, terdakwa sering tidak mengerti prosedur hukum dan cara-cara efisien untuk membantah atau menerima bukti. Jadi dia tidak seimbang dengan lawannya (penuntut umum) dalam proses persidangan.

d. Terdakwa harus diberi kesempatan untuk mengajukan pembelaan dan harus diperkenankan menjumpai dan berkorespondensi secara pribadi dengan penasihat hukumnya. Dia juga harus diijinkan berhadapan dan menguji silang dengan penuntut, saksi-saksi yang memberatkannya, dan terdakwa lainnya.

2. Hak pemeriksaan pengadilan

Dengan tujuan untuk mengamankan dan melindungi hak-hak individu terhadap penyalahgunaan kekuasaan eksekutif, Islam telah meletakkan hak, jika terdakwa diadili di muka pengadilan dan diadili secara terbuka.

3. Hak atas peradilan yang adil dan tidak memihak

Islam menaruh tekanan yang besar dalam mewujudkan keadilan dan kesamaan di antara manusia dalam semua segi kehidupan, khususnya di hadapan mereka yang memutuskan perkaranya. Para hakim ditugaskan untuk menjalankan tugasnya dengan adil dan tidak berpihak. Pernah terjadi di masa Rasulullah saw., seorang wanita dari satu suku yang kuat didakwa kasus pencurian. Beberapa anggota keluarga wanita itu pergi menjumpai Rasulullah saw. meminta pembebasan si wanita tadi dari hukuman yang ditentukan. Rasulullah dengan tegas menolak perantaraan itu dengan menyatakan: "Seandainya Fatimah binti Muhammad mencuri, ikatan keluarganya tidak dapat menyelamatkannya dari hukuman had."15

4. Hak untuk meminta ganti rugi karena putusan yang salah

Jika seorang hakim menjatuhkan putusan yang salah secara tidak disengaja, terhukum berhak atas kompensasi dari

${ }^{15}$ Topo Santoso, Membumikan Hukum Pidana Islam, (Jakarta: Gema Insani, 2003), 18. 
baitul maal (perbendaharaan negara) sebagai tambahan haknya untuk banding dan pengaduan kepada wali alMazalim. Apabila hakim sengaja bertindak tidak adil dan mengeluarkan suatu putusan yang tidak adil untuk keuntungan seseorang karena ia terhormat, kaya, atau berkuasa, hakim itu harus dihukum dengan pemecatan dan korban berhak atas ganti rugi dari hakim tersebut.

5. Keyakinan sebagai dasar dari terbuktinya kejahatan

Hukum Islam meletakkan asas praduga tak bersalah sebagai landasan dari aturan-aturan pidana substantive dan procedural. Sebagai konsekuensinya, keraguan yang belum dapat dihilangkan harus menjadi keuntungan bagi terdakwa, bukan merugikannya. Dengan demikian, keraguan itu dapat menjadi dasar untuk putusan bebas dan tidak dapat menjadi dasar bagi terbuktinya kejahatan, karena penghukuman harus didasarkan pada ketegasan dan keyakinan. Contoh dari Rasulullah saw yang diikuti para Khulafa Rasyidun penerus beliau, yakni tuduhan tanpa bukti yang nyata adalah tidak cukup dan seorang penuduh, yang menjadi pihak berkepentingan, tidak dapat mengajukan bukti tunggal untuk menghukum seorang pelaku tindak pidana.

\section{Implementasi Hak-Hak Anak dalam Proses Pemeriksaan Sidang Pengadilan Anak di Pengadilan Negeri Sidoarjo}

Dalam proses penerapan hukum struktur peradilan pidana anak yang terakhir adalah hakim pemutus perkara anak yang melakukan tindak pidana. Undang-Undang Pengadilan Anak menentukan bahwa hakim pemutusnya adalah hakim anak. Sesuai Pasal 55 Undang-Undang No. 3 Tahun 1997, dalam perkara anak yang melakukan tindak pidana, penuntut umum, penasihat hukum, pembimbing kemasyarakatan (PK), orang tua/wali/orang tua asuh, dan saksi wajib hadir di sidang anak. Pada prinsipnya tindak pidana yang dilakukan oleh anak adalah tanggung jawab anak itu sendiri, akan tetapi oleh karena terdakwa adalah seorang 
anak, maka tidak dapat dipisahkan kehadiran orang tua, wali atau orang tua asuhnya. Adapun acara pengadilan anak diuraikan pada bagian berikut ini. ${ }^{16}$

Tata ruang sidang pengadilan anak ditata berdasarkan ketentuan sebagaimana ketentuan Pasal 230 ayat (3) KUHAP sebagai berikut:

a. Tempat meja dan kursi hakim terletak lebih tinggi dari tempat penuntut umum, terdakwa, penasihat hukum, dan pengunjung.

b. Tempat panitera terletak di belakang sisi kanan tempat hakim ketua sidang.

c. Tempat penuntut umum terletak di sisi kanan depan hakim.

d. Tempat terdakwa dan penasihat hukum terletak di sisi kiri depan dari tempat hakim dan tempat terdakwa di sebelah kanan tempat penasihat hukum.

e. Tempat kursi pemeriksaan terdakwa dan saksi terletak di depan tempat hakim.

f. Tempat saksi atau ahli yang telah didengar terletak di belakang kursi pemeriksaan.

g. Tempat pengunjung terletak di belakang tempat saksi yang telah didengar.

h. Bendera nasional ditempatkan di sebelah kanan meja hakim dan panji pengayoman ditempatkan disebelah kiri meja hakim, sedangkan lambing negara ditempatkan di dinding bagian atas di belakang meja hakim.

i. Tempat rohaniawan terletak di sebelah kiri tempat panitera.

j. Tempat sebagaimana dimaksud huruf a sampai I di atas diberi tanda pengenal.

k. Tempat petugas keamanan di bagian dalam pintu masuk utama ruang sidang dan di tempat lain yang dianggap perlu.

Dalam pemeriksaan sidang anak yang melakukan tindak pidana, para pejabat pemeriksa yaitu hakim, penuntut umum, dan 
penasihat hukum tidak memakai toga. Panitera yang bertugas membantu hakim juga tidak memakai jas. Semua pakaian kebesaran tersebut tidak dipakai pejabat pemeriksa, dimaksudkan agar dalam persidangan tidak menimbulkan kesan menakutkan atau menyeramkan terhadap anak yang diperiksa. Selain itu agar dengan pakaian biasa dapat menjadikan persidangan berjalan lancar dan penuh kekeluargaan. ${ }^{17}$

Pemeriksaan sidang anak pada dasarnya dilakukan dengan hakim tunggal (Pasal 11 ayat (1) Undang-Undang No. 3 Tahun 1997) dengan sidang tertutup. Dengan hakim tunggal bertujuan agar sidang anak dapat diselesaikan dengan cepat. Memang pada prinsipnya bahwa penyelesaian perkara anak dapat dilakukan dengan waktu singkat/cepat agar anak tidak berlama-lama mendapat perlakuan terkait pemberian sanksi terhadap kenakalan yang telah dilakukannya.

Perkara anak yang disidangkan dengan hakim tunggal adalah perkara-perkara pidana yang ancaman hukumannya lima tahun atau ke bawah dan pembuktiannya mudah atau tidak sulit. Apabila tindak pidananya diancam dengan hukuman penjara diatas lima tahun dan pembuktiannya sulit, maka berdasarkan Pasal 11 ayat (2) Undang-Undang No. 3 Tahun 1997, perkara tersebut diperiksa dengan hakim majelis.

Sesuai Pasal 56 Undang-Undang No. 3 Tahun 1997, sebelum sidang dibuka, hakim memerintahkan kepada pembimbing kemasyarakatan agar menyampaikan laporan hasil penelitian kemasyarakatan mengenai anak yang bersangkutan. Ini artinya pembimbing kemasyarakatan menyampaikan laporannya secara tertulis. Dan kelak bila diperlukan pembimbing kemasyarakatan dapat memberikan kesaksian di depan pengadilan anak. Maksud diberikannya laporan sebelum sidang dibuka adalah agar cukup waktu bagi hakim untuk mempelajari laporan hasil penelitian kemasyarakatan itu. Oleh karena itu laporan tidak diberikan pada 
saat sidang berlangsung, tetapi beberapa waktu sebelumnya. Adapun laporan hasil penelitian kemasyarakatan sekurangkurangnya memuat data individu anak dan data keluarga anak yang bersangkutan serta kesimpulan atau pendapat dari pembimbing kemasyarakatan yang membuat laporan hasil penelitian kemasyarakatan.

Selanjutnya hakim membuka sidang terbuka untuk umum (Pasal 8 ayat (1) Undang-Undang No. 3 Tahun 1997). ${ }^{18}$ Terdakwa anak lalu dipanggil masuk keruangan sidang bersama orang tua, wali atau orang tua asuh, penasihat hukum, dan pembimbing kemasyarakatan. Selama dalam persidangan, terdakwa anak didampingi oleh orang tua, wali, atau orang tua asuh, penasihat hukum, dan pembimbing kemasyarakatan. Hakim lalu memeriksa identitas terdakwa anak, dan setelah itu hakim mempersilahkan jaksa penuntut umum anak membacakan surat dakwaannya. Setelah itu, kalau ada kepada terdakwa atau penasihat hukumnya diberi kesempatan untuk mengajukan tangkisan atau eksepsi atas dakwaan jaksa penuntut umum.

Sebagaimana diketahui di atas, bahwa setelah sidang dibuka, terdakwa dipanggil masuk ke ruang sidang bersama orang tua, wali, atau orang tua asuh, penasihat hukum, dan pembimbing kemasyarakatan. Dalam mendampingi terdakwa anak di persidangan, penasihat hukum mempunyai fungsi membela kepentingan hukum terdakwa di persidangan, ia berperan aktif dalam rangka mengungkapkan kebenaran materil terhadap perkara yang sedang dihadapi oleh terdakwa. Sedangkan orang tua, wali atau orang tua asuh dan pembimbing kemasyarakatan

\footnotetext{
18 Sidang dapat bersifat terbuka apabila: "dalam hal tertentu dan dipandang perlu" pemeriksaan sidang anak dapat dilakukan dengan sidang terbuka (Pasal 8 ayat (2) Undang-Undang No. 3 Tahun 1997). Dalam penjelasan pasal dirumuskan bahwa pada prinsipnya pemeriksaan perkara anak harus dilakukan secara tertutup. Walaupun demikian, dalam hal tertentu dan dipandang perlu, hakim dapat menetapkan pemeriksaan perkara dilakukan secara terbuka, tanpa mengurangi hak anak. "hal tertentu dan dipandang perlu" tersebut antara lain karena sifat dari keadaan perkara harus dilakukan secara terbuka. Suatu sifat perkara akan diperiksa secara terbuka misalnya perkara pelanggaran lalu lintas, sedangkan dilihat dari keadaan perkara misalnya pemeriksaan perkara di tempat kejadian perkara.
} 
lebih banyak bersifat pasif, hanya pemerhati jalannya persidangan. Mereka tidak mempunyai hak untuk membela kepentingan terdakwa seperti mengajukan keberatan terhadap surat dakwaan, bertanya kepada saksi maupun terdakwa. Meskipun demikian tidak berarti tidak mempunyai hak sama sekali, karena mereka diberi kesempatan untuk mengemukakan hal ikhwal yang bermanfaat bagi anak sebelum hakim mengucapkan putusannya (Pasal 59 ayat (1) Undang-Undang No. 3 Tahun 1997).

Pada asasnya, setiap saksi didengar di persidangan dihadiri oleh terdakwa, dengan maksud agar terdakwa mengetahui apa yang diterangkan oleh saksi dalam mengungkapkan terjadinya peristiwa tindak pidana dimana terdakwa yang didakwa sebagai pelakunya. Sehubungan dengan itu, terdakwa mempunyai kesempatan untuk menyanggah keterangan saksi tentang hal-hal yang tidak benar dari keterangan itu.

Orang yang diajukan sebagai saksi, terutama diambil dari orang-orang yang kebetulan berada di sekitar tempat kejadian, dengan tujuan agar mereka mudah mengungkapkan jalannya peristiwa tindak pidana. Sebelum memberikan keterangan di persidangan, saksi diwajibkan mengangkat sumpah lebih dahulu, bahwa ia akan menerangkan dengan benar dari apa yang dilihat dan didengar atau yang dialami sendiri.

Apabila saksi tidak menerangkan dengan benar dan telah diperingatkan oleh hakim yang memimpin sidang pengadilan, tetapi ternyata saksi tetap pada keterangannya, maka berdasarkan Pasal 174 ayat (2) KUHAP, hakim ketua sidang karena jabatannya atau atas permintaan penuntut umum atau terdakwa, dapat memerintahkan supaya saksi tersebut ditahan dan selanjutnya dituntut dengan dakwaan sumpah palsu. Saksi yang demikian dapat dipidana berdasarkan Pasal 242 KUHP.

Hadirnya terdakwa pada waktu pemeriksaan saksi, mempunyai keuntungan-keuntungan sebagaimana di atas. Dalam perkara anak tidak selalu demikian, pada tingkat pemeriksaan saksi dapat tidak dihadiri oleh terdakwa. Sesuai ketentuan Pasal 58 
ayat (1) Undang-Undang No. 3 Tahun 1997 tentang Pengadilan Anak, hakim dapat memerintahkan agar terdakwa dibawa ke luar sidang. Hal ini dimaksudkan untuk menghindari adanya hal yang memengaruhi jiwa anak. Tidak semua anak yang mempunyai sikap mental yang kuat untuk bisa mendengarkan secara langsung keterangan orang lain yang mengungkapkan perbuatannya yang kurang atau tidak baik. Bagi yang tidak bisa mendengarkan dan ini tetap dipaksakan akan berakibat tidak baik bagi perkembangan anak yang bersangkutan. Kalau terdakwa dikeluarkan dari persidangan, bukan berarti orang tua, wali atau orang tua asuhnya, penasihat hukum dan pembimbing kemasyarakatan juga ikut dikeluarkan, tetapi mereka tetap berada di persidangan.

Hakim yang memeriksa perkara anak, berwenang melakukan penahanan terhadap terdakwa anak untuk kepentingan pemeriksaan paling lama 15 (lima belas) hari. Apabila penahanan itu merupakan penahanan lanjutan, penahanannya dihitung sejak perkara anak dilimpahkan penuntut umum ke pengadilan. Sedang apabila bukan penahanan lanjutan, karena terdakwa tidak pernah ditahan di tingkat penyidikan maupun penuntutan, maka tergantung kepada hakim mulai kapan perintah penahanan itu dikeluarkan selama perkara belum diputus.

Jika jangka waktu 15 hari tersebut pemeriksaan sidang pengadilan belum selesai, penahanan dapat diperpanjang oleh Ketua Pengadilan Negeri untuk paling lama 30 (tiga puluh) hari. Jadi untuk kepentingan pemeriksaan di sidang, terdakwa dapat ditahan maksimal 45 (empat puluh lima) hari. Namun apabila jangka waktu itu terlampaui, sedangkan perkara belum diputus oleh hakim, maka terdakwa harus dikeluarkan dari tahanan demi hukum. ${ }^{19}$

Terakhir pada waktu pembacaan putusan, sebelum hakim mengucapkan putusannya hakim member kesempatan kepada orang tua, wali, atau orang tua asuh untuk mengemukakan segala 
hal ikhwal yang bermanfaat bagi anak. Dalam putusannya hakim wajib mempertimbangkan laporan hasil penelitian kemasyarakatan yang dilakukan oleh Pembimbing Kemasyarakatan, dan putusan harus diucapkan dalam sidang yang terbuka untuk umum. Hal ini dimaksudkan untuk mengedepankan sikap objektif dari suatu peradilan.

Implementasi Hak-Hak Anak yang Melakukan Tindak Pidana di Pengadilan Negeri Sidoarjo dalam Perspektif Hukum Islam

Sebagaimana telah dijelaskan bahwasanya untuk menghindarkan dan memutuskan persengketaan dalam menegakkan hukum di kalangan masyarakat, maka wajib adanya lembaga peradilan. ${ }^{20}$ Lembaga peradilan sebenarnya adalah lembaga yang mempunyai tugas menampakkan hukum agama. Hakim hanya menerapkannya ke dalam alam kenyataan, bukan menetapkan sesuatu yang belum ada. ${ }^{21}$

Dalam Undang-Undang Pengadilan Anak juga memegang prinsip menegakkan keadilan, dengan ditegakkannya keadilan, maka peradilan-peradilan yang tugasnya memeriksa, mengadili, dan memutus persengketaan di kalangan masyarakat tak terkecuali Pengadilan Negeri Sidoarjo yang dalam kedudukannya memeriksa dan memutus perkara di tingkat pertama sebagai wewenang yang diberikan oleh Undang-Undang Pokok Kekuasaan Kehakiman.

Jadi jelas bahwa antara hukum acara pidana Islam dengan Undang-Undang Pengadilan Anak sama-sama bertujuan menegakkan keadilan, tidak terkecuali keadilan mengenai hak-hak bagi tersangka selama dalam proses pemeriksaan di sidang pengadilan. Dengan ditegakkannya fungsi dan peranan peradilan sebagaimana Pengadilan Negeri Sidoarjo yang mempunyai wewenang pokok yaitu memeriksa dan memutus perkara, tidak

${ }^{20}$ Sayyid Sabiq, Figh Sunnah, (Bandung: Al-Ma'arif, 1987), 14.

${ }^{21}$ Hasby Ash Shiddieqy, Peradilan dan Hukum Acara Islam, (Semarang: Pustaka Putra, 1997), 34. 
terkecuali wewenangnya dalam memeriksa dan memutus perkara pidana yang dilakukan oleh anak.

a. Pemeriksaan di Persidangan Anak

Islam sebagai agama yang rahmatan lil alamin, menghargai betul tentang hak-hak seseorang. Islam telah menetapkan prinsip bahwa tidak ada warga negara yang boleh dimasukkan ke dalam penjara kecuali telah terbukti kesalahannya pada pengadilan terbuka. Penangkapan seseorang atas dasar kecurigaan dan memasukkannya ke dalam penjara tanpa proses pemeriksaan pengadilan yang layak dan tanpa memberikan kesempatan yang wajar kepadanya untuk mengajukan pembelaan adalah tidak diizinkan dalam Islam. ${ }^{22}$

Adapun pemerintahan suatu negara menyangka kepada seseorang dari warganya atau kemungkinan melakukan tindak pidana dikemudian hari, maka pemerintahan tersebut harus memberikan alasan yang kuat terhadap penangkapan tersangka yang dicurigai tersebut di muka pengadilan dan pihak yang dicurigai atau tersangka harus diberi kesempatan untuk mengajukan pembelaannya. Dan apabila kecurigaan pemerintah terbukti, maka pihak tersangka atau orang yang dicurigai harus diberi tahu berapa lama ia harus berada pada tahanan. Oleh karena itu, masyarakat harus mengetahui tentang tuduhan yang diajukan oleh pemerintah, demikian pula pembelaan yang diajukan tersangka dan diberikan kesempatan untuk menyaksikan dan mengetahui bahwa telah dilaksanakan peradilan yang sesuai dengan UndangUndang. ${ }^{23}$

Pada prinsipnya, peradilan anak yang dilaksanakan di Pengadilan Negeri Sidoarjo telah sesuai dengan prinsip yang disyariatkan oleh Islam di atas, dimana anak yang melakukan

22 Maulana Abul A'la Maududi, Hak-Hak Asasi Manusia dalam Islam, (Jakarta: PT. Bumi Aksara 1995), 26.

${ }^{23}$ Ibid., 27. 
tindak pidana yang dikenakan penahanan berhak diberitahukan tentang penahanan dirinya oleh pejabat yang berwenang pada semua tingkatan pemeriksaan dalam proses peradilan, kepada keluarganya atau orang lain yang serumah dengannya ataupun orang lain yang bantuannya dibutuhkan oleh anak yang melakukan tindak pidana untuk mendapatkan bantuan hukum atau jaminan bagi penangguhannya. Dan setiap anak yang melakukan tindak pidana sejak saat ditangkap atau ditahan berhak mendapat bantuan hukum dari seseorang atau lebih penasihat hukum selama dalam waktu dan pada setiap tingkat pemeriksaan yang berguna untuk membantunya dalam melakukan pembelaan dalam peradilannya.

b. Ganti Rugi

Upaya dalam mewujudkan perlindungan hak-hak asasi manusia tidak terkecuali hak anak yang melakukan tindak pidana yang tercantum dalam KUHAP adalah adanya lembaga ganti kerugian. Ganti rugi ini adalah hak bagi seseorang karena penangkapan, penahanan yang tidak dibenarkan oleh Undang-Undang atau kekeliruan mengenai orangnya atau hukum yang diterapkan.

Dalam hukum acara pidana Islam, tindakan aparat penegak hukum dalam melakukan penangkapan, penahanan dengan tanpa prosedur atau ketentuan Undang-Undang atau salah dalam penangkapan, penahanan terhadap seseorang adalah perbuatan maksiat yang dapat dikenakan hukuman ta'zir. Perbuatan maksiat adalah tindakan tidak melaksanakan kewajiban sesuai hukum dan menjalankan keharaman yang telah ditetapkan Undang-Undang atau hukum.

Ta'zir telah disyari'atkan bagi setiap pelanggaran yang syar'i yang tidak menetapkan ukuran hukumnya atau sanksinya. Sedangkan pelanggar yang telah ditetapkan sanksinya oleh Syari', maka pelanggarnya dijatuhi sanksi yang telah ditetapkan kadarnya oleh syar'i. Bila sanksinya 
diserahkan kepada penguasa atau hakim untuk menetapkan jenis dan macam sanksinya, maka sanksi semacam inilah yang disebut dengan $\mathrm{ta}^{\prime} \mathrm{zir}^{24}$

Dengan ini jelaslah kiranya bahwa hukuman yang diserahkan kepada hakim untuk menentukannya, dalam ilmu fikih disebut dengan $t a^{\prime} z i$. Perkara $t a^{\prime} z i r$ merupakan medan yang cukup luas bagi para hakim, ia boleh menghukum orang-orang yang hendak dihukumnya, dan dengan berbagai bentuk hukuman tanpa terikat kepada sesuatu apapun juga baik dari segi jenisnya, banyaknya, kemaslahatannya, dan dimaksudkan sebagai preventif atau pendidikan, menegakkan kebebasan dan keadilan. Inilah pendirian yang dikehendaki oleh keabadian suatu syariat, sesuainya syariat (konsepsi pidana Islam) itu bagi setiap waktu, tempat, dan perkembangan zaman sampai pada hari kiamat. ${ }^{25}$

Dalam menetapkan hukum ta'zir tidak boleh melebihi hukuman hudud, ini pendapat dari sebagian fuqaha. Mereka mengatakan kadar sanksi ta'zir tidak boleh melebihi kadar sanksi had yang dikenakan pada jenis kemaksiatan. Adapun hadist yang menjadi dalil mereka adalah hadist yang diriwayatkan oleh Abi Bardah dari Nabi saw, bahwa beliau saw bersabda:

Barang siapa melebihi had pada selain had (hudud), maka ia termasuk kaum yang melampaui batas. ${ }^{26}$

Mereka juga berpendapat bahwa sanksi harus ditetapkan berdasarkan kadar kejahatan dan dosanya. Adapun kemaksiatan yang telah ditetapkan hadnya (sanksinya) lebih tinggi tingkatannya dari kemaksiatan lain yang tidak ditetapkan sanksinya. Oleh karena itu, pada perkara yang

${ }^{24}$ Abdurrahman al-Maliki, Sistem Sanksi dalam Islam, ( Bogor: Pustaka Thariqul Izzah, 2002), 240-24l.

${ }^{25}$ Syaikh Mahmud Syaltout, Islam Sebagai Aqidah dan Syariah, Alih bahasa: H. Bustani A. Gani dan Djohar Bahry, 139.

${ }^{26}$ Abdurrahman al-Maliki, Sistem Sanksi dalam Islam, 242. 
lebih ringan, yakni perkara yang tidak ditetapkan hadnya, sanksinya tidak boleh melebihi hudud. ${ }^{7}$ Oleh karena itu hakim harus berhati-hati dalam penjatuhan hukuman ketika terjadi syubhat, seperti dalam kaidah fiqhiyah yaitu: "Hindarkanlah pelaksanaan hudud jika ada kesamaran"28

Dari kaidah di atas dapat dijelaskan bahwa seorang hakim dalam berijtihad tentang suatu putusan hukuman harus berhati-hati dan dapatlah menghindari hukuman had jika dalam perkara pidana terjadi kesamaran dan ketidakjelasan, sehingga hak tersangka dapat tetap terjaga.

\section{Penutup}

Anak adalah bagian dari generasi muda, penerus cita-cita bangsa yang memerlukan pembinaan dan perlindungan dalam rangka menjamin pertumbuhan dan perkembangan fisik, mental dan sosial secara utuh, serasi, selaras, dan seimbang, yang belum memiliki kemampuan membedakan tindakan yang boleh dan tidak dibolehkan, sehingga acapkali akibat tindakannya mereka harus dihadapkan dengan hukum. Terhadap anak yang melakukan tindak pidana dimana mereka tidak bisa melindungi hak-haknya sendiri, perlu ada kontrol dari orang dewasa, dalam hal ini orang tua dan terkait proses beracara di peradilan tentunya bantuan hukum seorang penasehat hukum dan Pengadilan Negeri Sidoarjo sebagai lembaga penegak hukum harus dengan bijaksana dalam melaksanakan tugas dan kewajibannya dengan tetap mengayomi, melindungi, memberi pelayanan sehingga meskipun anak-anak yang nakal dan melakukan tindak pidana dalam kehidupannya dapat menjadi warga negara yang berguna bagi dirinya sendiri, agama, masyarakat, nusa dan bangsa. Yang

\footnotetext{
${ }^{27}$ Ibid.

${ }^{28}$ A, Djazuli, Fiqh Jinayah (Upaya Menanggulangi Kejahatan dalam Islam), (Jakarta: Raja Grafindo Persada, 2000), 86.
} 
semuanya itu tidak akan bisa terlepas dari peran, bantuan, dan dukungan lingkungan masyarakat di sekitarnya.

Implementasi hak anak yang melakukan tindak pidana menurut Undang-Undang No. 3 Tahun 1997 di Pengadilan Negeri Sidoarjo pada proses pemeriksaan di persidangan anak adalah anak yang melakukan tindak pidana berhak mendapatkan penjelasan mengenai tata cara persidangan dan kasusnya, mendapatkan pendampingan penasihat hukum selama persidangan dan berhak memilih sendiri penasihat hukumnya, berhubungan langsung dengan penasihat hukum dengan diawasi tanpa didengar oleh pejabat berwenang, mendapatkan fasilitas ikut serta memperlancar persidangan mengenai dirinya, mendapatkan perlindungan terhadap tindakan-tindakan yang merugikan, yang menimbulkan penderitaan mental, fisik, sosial, mendapatkan hak untuk menyatakan pendapat dan membela dirinya, mendapatkan perlakuan pembinaan/penghukuman yang positif, yang masih mengembangkan dirinya sebagai manusia seutuhnya, dan memohon ganti kerugian atas perlakuan yang menimbulkan penderitaan, karena ditangkap, ditahan, dituntut, ataupun diadili tanpa alasan yang berdasarkan undang-undang atau karena kekeliruan mengenai orangnya atau hukum yang diterapkan menurut cara yang diatur dalam KUHAP.

Menurut hukum Islam, pertanggungjawaban pidana anak didasarkan atas dua perkara, yaitu kekuatan berfikir dan pilihan (iradah dan ikhtiyar). Oleh karena itu kedudukan anak kecil berbeda-beda menurut perbedaan masa yang dilalui hidupnya, mulai dari waktu kelahirannya sampai masa memiliki kedua perkara tersebut. Hasil penyelidikan para fuqaha mengatakan bahwa masa tersebut ada tiga, yaitu: masa tidak adanya kemampuan berfikir, masa kemampuan berfikir lemah, dan masa kemampuan berfikir penuh. Dimana pada proses peradilan anak, anak yang melakukan tindak pidana berhak atas pembelaan dirinya baik yang dilakukan dirinya maupun bantuan dari 
penasihat hukum dan berhak meminta ganti rugi karena putusan yang salah.

\section{Daftar Pustaka}

Anshori, Ibnu. Perlindungan Anak Menurut Perspektif Islam. Jakarta: KPAI, 2007.

Ashshiddieqy, Hasby. Peradilan dan Hukum Acara Islam. Semarang: Pustaka Putra, 1997.

Departemen Agama RI. Al-Quran dan Terjemahannya. Bandung: Diponegoro, 2008.

Djazuli, A. Fiqh Jinayah (Upaya Menanggulangi Kejahatan dalam Islam). Jakarta: Raja Grafindo Persada, 2000.

Hanafi, Ahmad. Asas-Asas Hukum Pidana Islam. Jakarta: Bulan Bintang, 1990.

Maliki (al-), Abdurrahman. Sistem Sanksi dalam Islam. Bogor: Pustaka Thariqul Izzah, 2002.

Maududi, Maulana Abul A'la. Hak-Hak Asasi Manusia dalam Islam. Jakarta: PT. Bumi Aksara 1995.

Nashriana. Perlindungan Hukum Pidana Bagi Anak di Indonesia. Jakarta: Raja Grafindo Persada, 2011.

Rahman, Abdur. Tindak Pidana dalam Syariat Islam. Jakarta: Rineka Cipta, 1992.

Sabiq, Sayyid. Fiqh Sunnah. Bandung: Al-Ma'arif, 1987.

Santoso, Topo. Membumikan Hukum Pidana Islam. Jakarta: Gema Insani, 2003.

Sinaga, Desbenneri. Wawancara, Sidoarjo, 1 Mei 2013.

Soe. "Polisi Tangkap Kelompok Remaja Pencuri Motor", Jawa Pos, 9 April 2013.

Wahyono, Agung dan Siti Rahayu. Tinjauan Tentang Peradilan Anak di Indonesia. Jakarta: Sinar Grafika, 1993.

Belasan Anggota Geng Klewang Masih Anak-Anak, http://www.news.viva.co.id/read/25802/belasan-anggotageng-motor-klewang-masih-anak-anak, diakses 28 Mei 2013. 